PNL-3255

UC-78

\title{
The Dependence of LMFBR
}

Fueling Requirements on

Plutonium Isotopic

Composition
U. P. Jenquin
D. F. Newman

December 1979

Prepared for the U.S. Department of Energy under Contract EY-76-C-06-1830

Pacific Northwest Laboratory Operated for the U.S. Department of Energy by Battelle Memorial Institute 


\title{
NOTICE
}

This report was prepared as an account of work sponsored by the United States Government. Neither the United States nor the Department of Energy, nor any of their employees, nor any of their contractors, subcontractors, or their employees, makes any warranty, express or implied, or assumes any legal liability or responsibility for the accuracy, completeness or usefulness of any information, apparatus, product or process disclosed, or represents that its use would not infringe privately owned rights.

The views, opinions and conclusions contained in this report are those of the contractor and do not necessarily represent those of the United States Government or the United States Department of Energy.

\author{
PACIFIC NORTHWEST LABORATORY \\ operated by \\ BATTELLE \\ for the \\ UNITED STATES DEPARTMENT OF ENERGY \\ Under Contract EY-76-C-06-1830
}

\author{
Printed in the United States of America \\ Available from \\ National Technical Information Service \\ United States Department of Commerce \\ 5285 Port Royal Road \\ Springfield, Virginia 22151
}

Price: Printed Copy s $\therefore$ Microfiche $\$ 3.00$

$\begin{array}{cc}\text { •Pages } & \begin{array}{c}\text { NTIS } \\ \text { Selling Price }\end{array} \\ 001-025 & \$ 4.00 \\ 026-050 & \$ 4.50 \\ 051-075 & \$ 5.25 \\ 076-100 & \$ 6.00 \\ 101-125 & \$ 6.50 \\ 126-150 & \$ 7.25 \\ 151-175 & \$ 8.00 \\ 176-200 & \$ 9.00 \\ 201-225 & \$ 9.25 \\ 226-250 & \$ 9.50 \\ 251-275 & \$ 10.75 \\ 276-300 & \$ 11.00 \\ & \end{array}$


PNL -3255

UC-78

\section{5}

THE DEPENDENCE OF LMFBR FUELING REQUIREMENTS ON PLUTONIUM ISOTOPIC COMPOSITION

U. P. Jenquin

D. F. Newman

December 1979

Prepared for

the U.S. Department of Energy

Under Contract EY-76-C-06-1830

Pac if ic Northwest Laboratory

Richland, Washington 99352 


\section{CONTENTS}

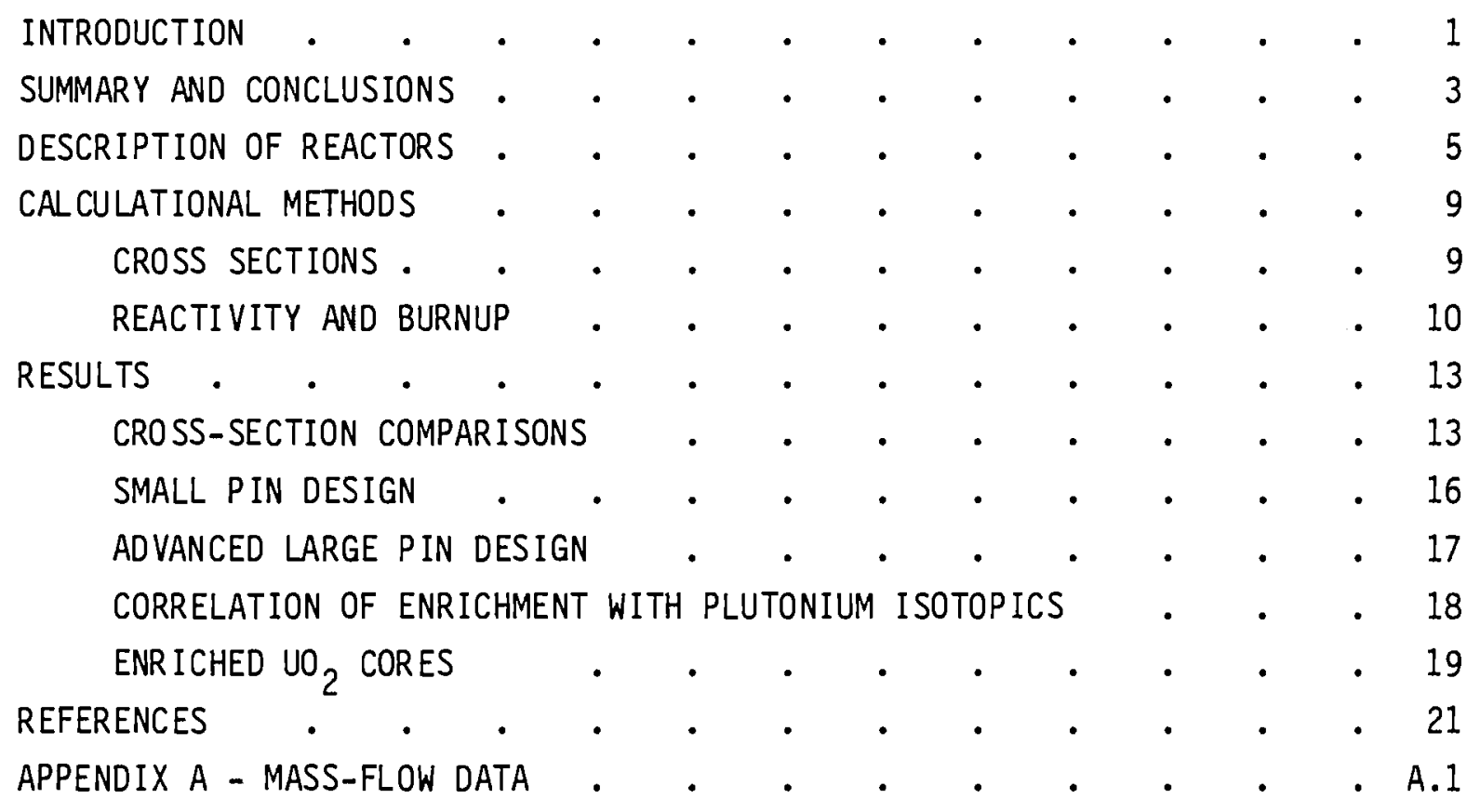




\section{INTRODUCTION}

When the liquid metal fast breeder reactors (LMFBRs) start up, plutonium from thermal reactors will be required to enrich the reactor fuel. Neutronics analyses performed to determine the fueling requirements for an 800 megawatt electric (MWe) breeder reactor are described in this report. This study was initiated when it was assumed that thermal reactor plutonium recycle would take place prior to the introduction of the breeder. Therefore, a range of plutonium compositions was fed into the LMFBR and the fueling requirements were determined for these various compositions. Depleted uranium was used as the diluent.

The analyses were performed for two reactor designs--a reference small fuel pin design and an advanced large fuel pin design. Burnup calculations were performed to determine the compositions of the discharge plutonium. The instantaneous breeding ratio at mid-cycle was calculated for each plutonium composition. Plutonium isotopic coefficients were determined so that fueling requirements could be predicted without having to analyze every particular plutonium composition in question. As a comparison, analyses were also done for an LMFBR fueled with uranium enriched in ${ }^{235} U$ rather than plutonium.

This study was funded under the Fuels Refabrication and Development Program and related Nuclear Fuel Cycle and Production Division Programs. 


\section{SUMMARY AND CONCLUSIONS}

Neutronics analyses were performed for two LMFBR designs to determine the fueling requirements, mass flows, and breeding ratios using various plutonium compositions. Correlation coefficients relating the fueling requirements to isotopic compositions were also determined.

As the ${ }^{242} \mathrm{Pu}$ content of the plutonium increases, the fueling requirement increases because ${ }^{242} \mathrm{Pu}$ neither fissions appreciably nor forms another fissile isotope upon neutron capture. Because of its low capture-to-fission ratio, ${ }^{241} \mathrm{Pu}$ is the most valuable isotope. The fertile isotopes ${ }^{238} \mathrm{Pu}$ and ${ }^{240} \mathrm{Pu}$ are also valuable because they fission as well as create a fissile isotope upon neutron capture. As the ${ }^{238} \mathrm{Pu}$ and ${ }^{240} \mathrm{Pu}$ content of the plutonium increases, the fueling requirement increases. For plutonium compositions with high ${ }^{238} \mathrm{Pu}$ and ${ }^{240} \mathrm{Pu}$ contents, the breeding ratio is very high.

The results for the advanced large pin design are nearly the same as the results for the small pin design because the fuel, structural, and sodium volume fractions are nearly identical. The largest cause of the differences in results between the two designs is the longer residence times of the core and blankets for the advanced large pin design.

If the uranium is enriched with ${ }^{235} \mathrm{U}$ rather than plutonium, the fissile fraction required is about $17 \%$. The conversion ratio drops to 0.96 for these cases. 


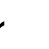




\section{DESCRIPTION OF REACTORS}

Calculations were done for two LMFBR designs using advanced oxide fuel. The designs are based on a reference small fuel pin and on an advanced large fuel pin. The reactor data developed by $H_{E D L}{ }^{(1)}$ are given in Table 1 for the cores and axial blankets and Table 2 for the radial blankets.

The designs are symmetrical about the midplane. The core is divided into two enrichment regions in order to reduce power peaking. The axial blanket is 18 in. thick on each end of the core. The primary difference between the two cores is the size of the fuel pins. Additional design parameters are given in Reference 1.

One-half of the core and one-fourth of the radial blanket are replaced each year in the small pin design. In the advanced large pin design, onethird of the core and one-sixth of the radial blanket are replaced each year. The uranium in the core and blankets was depleted to 0.2 atom percent ${ }^{235} U$. The structural material was assumed to be 316 stainless steel with atom percentages of $69,18,11$, and 2 for iron, chromium, nickel, and molybdenum, respectively.

The isotopic compositions of the different types of plutonium are listed in Table 3. The LMFBR type (as calculated by HEDL ${ }^{(1)}$ ) is a mixture of the plutonium discharged from the inner core, outer core, axial blanket, and radial blanket of an LMFBR with the small pin design. The other plutonium types were obtained from light water reactor discharged fue 1. (2) The first $\mathrm{UO}_{2}$ plutonium is recovered from fuel used to start up a PWR and is discharged after one cycle or at $15 \mathrm{GWd} / \mathrm{T}$. The equilibrium $\mathrm{UO}_{2}$ plutonium is recovered from a PWR on an equilibrium once-through cycle discharged at 33 GWd/T. The second $U$ plutonium is obtained from a BWR after the uranium is recovered, re-enriched, and re-irradiated twice. The third U plutonium results from the same sequence, three times in a PWR. The first Pu plutonium is recovered from PWR mixed oxide fuel after the plutonium has been recycled through the reactor once. The third $\mathrm{Pu}$ plutonium is recovered after it has been recycled through the PWR three times. 
TABLE 1. Core and Axial Blanket Design Parameters Using Advanced Oxide Fuel

\begin{tabular}{|c|c|c|}
\hline Design Characteristic & Small Pin & $\begin{array}{l}\text { Advanced } \\
\text { Large Pin }\end{array}$ \\
\hline Core radius, in. & 58.9 & 60.1 \\
\hline Active fuel length, in. & 36.0 & 36.0 \\
\hline Axial blanket thickness, in. & 36.0 & 36.0 \\
\hline Pin outer diameter, in. & 0.23 & 0.30 \\
\hline Cladding thickness, in. & 0.010 & 0.013 \\
\hline Pins per subassembly & 271 & 271 \\
\hline Subassembly pitch, in. & 4.886 & 6.3217 \\
\hline Number of subassemblies & 527 & 328 \\
\hline Mass of fue 1 in core, $\mathrm{kg}$ & 23968 & 25388 \\
\hline Mass of fuel in axial blanket, $\mathrm{kg}$ & 23968 & 25388 \\
\hline Fuel volume fraction & 0.4237 & 0.4340 \\
\hline Steel volume fraction & 0.1668 & 0.1693 \\
\hline Sodium volume fraction & 0.3775 & 0.3690 \\
\hline Control volume fraction & 0.0272 & 0.0277 \\
\hline Average coolant temperature, ${ }^{\circ} \mathrm{C}$ & 470 & 438 \\
\hline
\end{tabular}

TABLE 2. Radial Blanket Design Parameters

\begin{tabular}{|c|c|c|}
\hline Design Characteristic & Small Pin & $\begin{array}{l}\text { Advanced } \\
\text { Large Pin }\end{array}$ \\
\hline Blanket thickness, in. & 16.3 & 16.6 \\
\hline Pin outer diameter, in. & 0.519 & 0.662 \\
\hline Cladding thickness, in. & 0.015 & 0.015 \\
\hline Pins per subassembly & 61 & 61 \\
\hline Number of subassemblies & 331 & 206 \\
\hline Mass of fuel in blanket, $\mathrm{kg}$ & 39190 & 40953 \\
\hline Fuel volume fraction & 0.5532 & 0.5532 \\
\hline Steel volume fraction & 0.1697 & 0.1697 \\
\hline Sodium volume fracton & 0.2771 & 0.2771 \\
\hline Average coolant temperature, ${ }^{\circ} \mathrm{C}$ & 315 & 315 \\
\hline
\end{tabular}


TABLE 3. Plutonium Isotopics Used to Fuel the LMFBR

\begin{tabular}{|c|c|c|c|c|c|c|c|}
\hline \multirow[b]{2}{*}{ Isotope } & \multicolumn{7}{|c|}{ Composition, atom per cent } \\
\hline & 1 st $\mathrm{UO}_{2}$ & Equil. $\mathrm{UO}_{2}$ & 2nd U & 3rd U & $\underline{1 \text { st } \mathrm{Pu}}$ & $\underline{3 r d P u}$ & $\underline{L M F B R}$ \\
\hline $\mathrm{Pu}-238$ & 0.39 & 1.55 & 15.00 & 35.75 & 2.21 & 3.74 & 0 \\
\hline $\mathrm{Pu}-239$ & 66.81 & 55.13 & 56.92 & 50.70 & 39.23 & 27.17 & 70.7 \\
\hline $\mathrm{Pu}-240$ & 21.73 & 23.89 & 16.98 & 7.50 & 30.51 & 28.34 & 24.8 \\
\hline Pu-241 & 9.34 & 14.17 & 9.14 & 5.47 & 17.87 & 21.47 & 3.0 \\
\hline $\mathrm{Pu}-242$ & 1.73 & 5.26 & 1.96 & 0.58 & 10.18 & 19.28 & 1.5 \\
\hline
\end{tabular}




\section{CALCULATIONAL METHODS}

To determine the fueling requirements and mass flows for the LMFBR designs, cross sections, reactivity, and burnup were calculated. The calculational methods are described below.

\section{CROSS SECTIONS}

Four-group cross sections were generated with $10 x^{(3)}$ by collapsing $30-$ group cross sections over spectra representing a core and radial blanket. Most of the 30-group cross sections are composed of the FTR Set $300^{(4)}$ data, which are based on ENDF/B-II data. Version IV data were used for Fe, $\mathrm{Ni}$, and ${ }^{238} \mathrm{Pu}$. For ${ }^{241} \mathrm{Am}$, preliminary Version $V$ data $(5,6)$ were used. Version IV data for $\mathrm{Fe}$ and $\mathrm{Ni}$ are substantially different than Version II data. For ${ }^{238} \mathrm{Pu}$ and ${ }^{241} \mathrm{Am}$, no data existed on the FTR Set 300 library. The halflife of ${ }^{241} \mathrm{Pu}$ was assumed to be 14.5 years. Energy boundaries of the four broad groups are given in Table 4 .

\begin{tabular}{|c|c|c|}
\hline Group No. & Lethargy Width & Energy Boundaries, eV \\
\hline 1 & 2.5 & $8.209 \times 10^{5}$ to $1.0 \times 10^{7}$ \\
\hline 2 & 2.0 & $1.111 \times 10^{5}$ to $8.209 \times 10^{5}$ \\
\hline 3 & 2.0 & $1.503 \times 10^{4}$ to $1.111 \times 10^{5}$ \\
\hline 4 & - & 0.0 to $1.503 \times 10^{4}$ \\
\hline
\end{tabular}

The 1DX code performs a one-dimensional diffusion theory calculation in 30 energy groups. The core consists of a uniform fuel mixture at a typical plutonium enrichment with appropriate isotopics. The radial blanket mixture was represented with appropriate volume-weighted isotopics of fuel, structural, and coolant materials. Cross sections were averaged over the core and over the radial blanket for several core enrichments using various plutonium isotopics. 


\section{REACTIVITY AND BURNUP}

Reactivity and burnup calculations were performed with the $2 \mathrm{DB}(7)$ code using the 4-group cross seactions generated with 1DX. The reactors were modeled as right cylinders assuming axial symetry. The cores were divided into two enrichment regions as shown in Figures 1 and 2. The number of mesh intervals used to represent each region is indicated in Figure 1 for the small pin design and Figure 2 for the advanced large pin design.

Each region was divided into multiple zones to represent fuel at different exposures. For the small pin design, four zones were used for the radial blanket and two zones were used for each of the other regions. For the advanced large pin design, six zones were used for the radial blanket and three zones were used for each of the other regions. Within each region these multiple zones were arrayed in a checkerboard type of pattern in order to approximate homogeneity.

The 2DB code also performs the burnup calculation on a zone basis. Onegroup cross sections are obtained by flux and volume weighting the four-group cross sections over each zone. The isotopics in each zone were updated every 182.5 days based on a total power of $1800 \mathrm{MWt}$. This corresponds to a full power of 2500 MWt with a capacity factor of $72 \%$.

After each year of exposure the appropriate fraction of fuel in each region was replaced by fresh fuel. Flux distributions, power distributions, mass inventories, reaction rates, and the instantaneous breeding ratio (BR) were calculated before and after the fresh fuel was charged. The instantaneous breeding ratio is defined as:

where

$$
B R=\frac{\sum_{c}^{U-238}+\sum_{c}^{P u-238}+\sum_{c}^{P u-240}}{\sum_{a}^{U-235}+\sum_{a}^{P u-239}+\sum_{a}^{P u-241}}
$$

\footnotetext{
$\sum$ is the macroscopic cross section

subscript $c$ refers to capture

subscript a refers to absorption.
} 


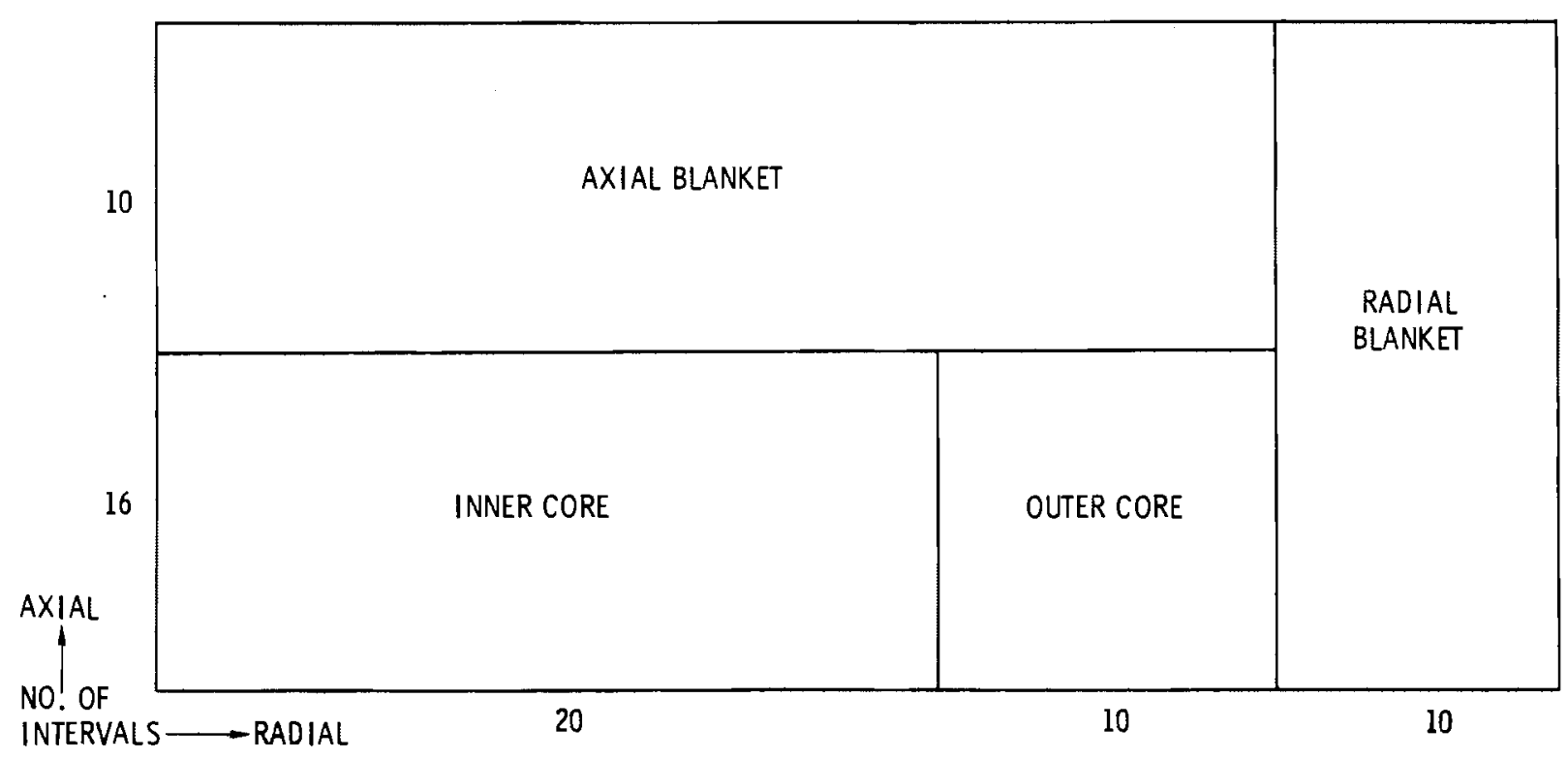

FIGURE 1. Smal1 Pin Design Mesh Layout

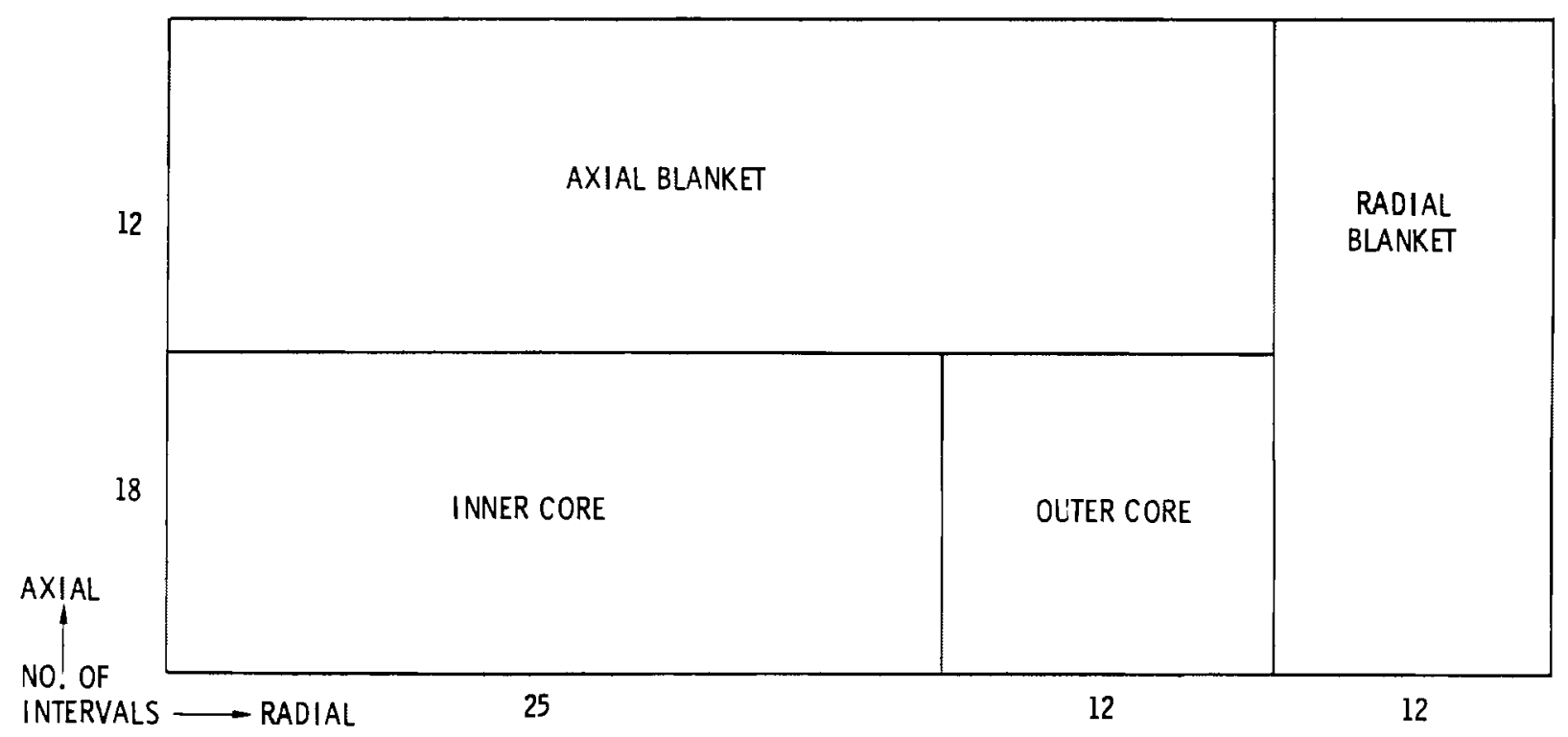

FIGURE 2. Advanced Large Pin Design Mesh Layout 


\section{RESULTS}

Based on the calculatonal methods described in the previous section, cross-section comparisions were made for several of the plutonium types listed in Table 3. Plutonium enrichment requirements for the small pin and advanced large pin designs were calculated and correlated with the various plutonium isotopics. A comparative calculation was also performed for uranium fuel enr iched in ${ }^{235} \mathrm{U}$.

\section{CROSS-SECTION COMPARISONS}

Four-group microscopic cross sections were generated with 1DX using the plutonium types listed in Table 3 except for the first $\mathrm{UO}_{2}$ and first Pu. In Table 5, values of the actinide cross sections are compared for three of the plutonium types. The values are nearly independent of the plutonium isotopic composition. Thus, using cross sections generated with other types of plutonium for the first $\mathrm{UO}_{2}$ and first $\mathrm{Pu}$ cases does not significantly affect the calculated reactivity and burnup.

A potential error results from using cross sections derived with an enrichment different than the enrichment converged on in 2DB. Table 6 shows the sensitivity of the 4-group microscopic cross sections to plutonium enrichment using equilibrium $\mathrm{UO}_{2}$ plutonium. The differences are small. If the enrichment used in $2 D B$ is within $1 \%$ of the enrichment used in 1DX, the error should be negligible.

The worth of the primary elements of 316 stainless steel structural material was estimated by comparing the reaction rate of each element to the total reaction rate in the reactor. The results are presented in Table 7 . As Table 7 shows, the total worth of the structural material is $44 \mathrm{mk}$ or 4.4\% in k. Each component contributes significantly to the total. 
TABLE 5. Sensitivity of the Microscopic Cross Sections to the Plutonium Composition (Sma11 Pin Design)

Fission, Barns

Absorption, Barns

\begin{tabular}{|c|c|c|c|c|c|c|c|}
\hline \multirow{2}{*}{\multicolumn{2}{|c|}{ Group No. }} & \multicolumn{3}{|c|}{ Fission, Barns } & \multicolumn{3}{|c|}{ Absorption, Barns } \\
\hline & & $\begin{array}{r}\text { Equil. } \mathrm{UO}_{2} \\
\quad 16.5 \% \mathrm{Pu}^{2} \\
\end{array}$ & $\begin{array}{l}3 r d \mathrm{U} ; \\
16.0 \% \mathrm{Pu}\end{array}$ & $\begin{array}{l}3 r d \mathrm{Pu} ; \\
20.0 \% \mathrm{Pu}\end{array}$ & $\begin{array}{l}\text { Equi1. } \mathrm{UO}_{2} ; \\
\quad 16.5 \% \mathrm{Pu}^{2} \\
\end{array}$ & $\begin{array}{l}3 r d \mathrm{U} ; \\
16.0 \% \mathrm{Pu} \\
\end{array}$ & $\begin{array}{l}\text { 3rd Pu; } \\
20.0 \% \mathrm{Pu}\end{array}$ \\
\hline$U-238$ & 1 & 0.3209 & 0.3215 & 0.3211 & 0.3786 & 0.3791 & 0.3789 \\
\hline & 2 & 0.0004 & 0.0004 & 0.0004 & 0.1398 & 0.1399 & 0.1398 \\
\hline & 3 & 0 & 0 & 0 & 0.3646 & 0.3653 & 0.3653 \\
\hline & 4 & 0 & 0 & 0 & 0.8739 & 0.8782 & 0.8814 \\
\hline $\mathrm{Pu}-238$ & 1 & 2.220 & 2.220 & 2.220 & 2.247 & 2.247 & 2.246 \\
\hline & 2 & 0.9972 & 0.9970 & 0.9972 & 1.118 & 1.117 & 1.118 \\
\hline & 3 & 0.6283 & 0.6289 & 0.6287 & 0.9896 & 0.9909 & 0.9905 \\
\hline & 4 & 1.695 & 1.550 & 1.674 & 3.539 & 3.133 & 3.465 \\
\hline $\mathrm{Pu}-239$ & 1 & 1.870 & 1.870 & 1.870 & 1.881 & 1.881 & 1.881 \\
\hline & 2 & 1.553 & 1.553 & 1.553 & 1.722 & 1.722 & 1.722 \\
\hline & 3 & 1.702 & 1.702 & 1.702 & 2.159 & 2.160 & 2.160 \\
\hline & 4 & 3.144 & 3.210 & 3.161 & 5.519 & 5.632 & 5.559 \\
\hline $\mathrm{Pu}-240$ & 1 & 1.533 & 1.534 & 1.533 & 1.595 & 1.595 & 1.595 \\
\hline & 2 & 0.2613 & 0.2613 & 0.2613 & 0.4441 & 0.4441 & 0.4441 \\
\hline & 3 & 0.0889 & 0.0889 & 0.0889 & 0.5063 & 0.5071 & 0.5067 \\
\hline & 4 & 0.1321 & 0.1354 & 0.1308 & 1.670 & 1.787 & 1.634 \\
\hline $\mathrm{Pu}-241$ & 3 & 2.579 & 2.581 & 2.580 & 3.140 & 3.142 & 3.141 \\
\hline & 4 & 5.755 & 5.878 & 5.729 & 7.134 & 7.290 & 7.103 \\
\hline $\mathrm{Pu}-242$ & 3 & 0.0398 & 0.0399 & 0.0399 & 0.3680 & 0.3687 & 0.3684 \\
\hline & 4 & 0.0194 & 0.0194 & 0.0196 & 1.432 & 1.520 & 1.315 \\
\hline
\end{tabular}


TABLE 6. Sensitivity of the Microscopic Cross Sections to the Equilibrium $\mathrm{UO}_{2}$ Plutonium Enrichment

\begin{tabular}{|c|c|c|c|c|c|}
\hline & & Fissio & Barns & Absorp & , Barns \\
\hline & Group No. & $16.5 \% \mathrm{Pu}$ & $15.3 \% \mathrm{Pu}$ & $16.5 \% \mathrm{Pu}$ & $15.3 \% \mathrm{Pu}$ \\
\hline U-238 & 1 & 0.3209 & 0.3208 & 0.3786 & 0.3786 \\
\hline & 2 & 0.0004 & 0.0004 & 0.1398 & 0.1399 \\
\hline & 3 & 0 & 0 & 0.3646 & 0.3651 \\
\hline & 4 & 0 & 0 & 0.8739 & 0.8759 \\
\hline Pu-238 & 1 & 2.220 & 2.220 & 2.247 & 2.247 \\
\hline & 2 & 0.9972 & 0.9961 & 1.118 & 1.117 \\
\hline & 3 & 0.6283 & 0.6288 & 0.9896 & 0.9907 \\
\hline & 4 & 1.695 & 1.708 & 3.539 & 3.605 \\
\hline Pu-239 & 1 & 1.870 & 1.870 & 1.881 & 1.881 \\
\hline & 2 & 1.553 & 1.552 & 1.722 & 1.722 \\
\hline & 3 & 1.702 & 1.702 & 2.159 & 2.160 \\
\hline & 4 & 3.144 & 3.197 & 5.519 & 5.610 \\
\hline Pu-240 & 1 & 1.533 & 1.533 & 1.595 & 1.595 \\
\hline & 2 & 0.2613 & 0.2608 & 0.4441 & 0.4436 \\
\hline & 3 & 0.0889 & 0.0889 & 0.5063 & 0.5069 \\
\hline & 4 & 0.1321 & 0.1329 & 1.670 & 1.705 \\
\hline Pu-241 & 3 & 2.579 & 2.581 & 3.140 & 3.142 \\
\hline & 4 & 5.755 & 5.846 & 7.134 & 7.249 \\
\hline Pu-242 & 3 & 0.0398 & 0.0399 & 0.3680 & 0.3686 \\
\hline & 4 & 0.0197 & 0.0194 & 1.432 & 1.463 \\
\hline
\end{tabular}

TABLE 7. Reactivity Worth of Steel Components

Element Worth, mk

$\begin{array}{lr}\mathrm{Fe} & 19 \\ \mathrm{Cr} & 8 \\ \mathrm{Ni} & 9 \\ \mathrm{Mo} & 8 \\ \text { Total } & 44\end{array}$


SMALL PIN DESIGN

The plutonium enrichment required for fueling the small pin design is summarized in Table 8 for the various types of plutonium. Large amounts of ${ }^{238} \mathrm{Pu}$ and ${ }^{240} \mathrm{Pu}$ do not force the enrichment up because these isotopes have relatively large fission cross sections and readily transmute into fissile isotopes $\left({ }^{239} \mathrm{Pu}\right.$ and $\left.{ }^{241} \mathrm{Pu}\right)$. The enrichment does increase with increasing ${ }^{242} \mathrm{Pu}$ content because ${ }^{242} \mathrm{Pu}$ does not fission appreciably and does not form another fissile isotope upon neutron capture.

TABLE 8. Plutonium Enrichment as a Function of Isotopics for the Small Pin Design

\begin{tabular}{|c|c|c|c|c|c|c|c|}
\hline Parameter & 1 st $\mathrm{UO}_{2}$ & Equil. $\mathrm{UO}_{2}$ & $3 \mathrm{rd} U$ & 1st Pu & 3rd Pu & 2nd U & LMFBR \\
\hline ment, $\% p u$ & 14.88 & 15.62 & 15.24 & 17.48 & 19.06 & 15.12 & 15.50 \\
\hline & 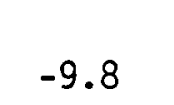 & 13.1 & +3.6 & -13.7 & -18.7 & -3.8 & -2.1 \\
\hline BR (2nd yr) & 1.386 & 1.423 & 1.724 & 1.498 & 1.554 & 1.530 & 1.390 \\
\hline BR (4th yr) & 1.383 & 1.420 & 1.721 & 1.495 & 1.551 & 1.527 & 1.387 \\
\hline
\end{tabular}

The calculations using plutonium with a high ${ }^{242} \mathrm{Pu}$ content may be somewhat in error because of the omission of ${ }^{243} \mathrm{Am}$ from the calculation. In two years about $8 \%$ of the ${ }^{242} \mathrm{Pu}$ is converted to ${ }^{243} \mathrm{Am}$. For the third $\mathrm{Pu}$ case where $19 \%$ of the plutonium is ${ }^{242} \mathrm{Pu}$, this means that the ${ }^{243} \mathrm{Am}$ content of the discharged fuel is $1-1 / 2 \%$ of the total actinides. The reactivity effect of not including ${ }^{243} \mathrm{Am}$ in the calculation is expected to be of the order of mk because of fast fissions; however, the isotope should be included in the calculation to accurately assess its value.

Also shown in Table 8 is the reactivity change over a cycle for equilibrium conditions. The minimum reactivity generally occurs at the end of the second year. Thereafter, the end-of-cycle reactivity increases slightly because of plutonium buildup in the radial blanket. The minimum reactivity 
using the third $U$ type of plutonium occurs at the initial loading. Thereafter, the reactivity increases because of the high breeding ratio.

The instantaneous breeding ratios for the second year and the fourth year are also given in Table 8. The difference in the two values is caused by the buildup of fissile material in the radial blanket. Generally, the lower the percentage of fissile isotopes in the plutonium, the higher the breeding ratio. A high percentage of ${ }^{238} \mathrm{Pu}$ also pushes the breeding ratio up, while a high percentage of ${ }^{242} \mathrm{Pu}$ holds the breeding ratio down because ${ }^{242} \mathrm{Pu}$ is not a fertile isotope.

The sensitivity of reactivity and breeding ratio to the enrichment requirement is given in Table 9 for some of the plutonium types.

\begin{tabular}{|c|c|c|}
\hline Type & $\Delta \mathrm{k} / \Delta \mathrm{E}, \mathrm{mk} / \% \mathrm{Pu}$ & $\triangle B R / \Delta E,(\% \quad P u)^{-1}$ \\
\hline 1 st $\mathrm{UO}_{2}$ & 24 & 0.068 \\
\hline Equil. $\mathrm{UO}_{2}$ & 25 & 0.071 \\
\hline 3rd U Recycle & 38 & 0.079 \\
\hline 1st Pu Recycle & 21 & 0.055 \\
\hline 3rd Pu Recycle & 20 & 0.054 \\
\hline
\end{tabular}

The annual feed and discharge masses by isotope are given for the various types of plutonium in Appendix A, Tables A.1 to A.7 for the small pin design. The values given are for the equilibrium situation. ADVANCED LARGE PIN DESIGN

The plutonium enrichment required for the advanced large pin design is summarized in Table 10 for the various types of plutonium. The fueling requirements are very close to those of the small pin design because, as noted earlier, the volume fractions of the fuel, structure, and moderator are nearly the same. The reactivity swing for the equilibirum cycle is also given in Table 10. The values are nearly the same as for the small pin design. 
TABLE 10. Plutonium Enrichment as a Function of Isotopics for the Advanced Large Pin Design

\begin{tabular}{|c|c|c|c|c|c|c|c|}
\hline Parameter & 1 st $\mathrm{UO}_{2}$ & Equil. $\mathrm{UO}_{2}$ & 3rd U & 1st Pu & 3 rd Pu & 2nd U & LMFBR \\
\hline richment, \% Pu & 14.84 & 15.60 & 15.09 & 17.47 & 19.11 & 15.02 & 15.37 \\
\hline $\begin{array}{l}\text { eactivity } \\
\text { wing, mk }\end{array}$ & -9.7 & -12.5 & +1.5 & -12.7 & -17.2 & -4.7 & -3.1 \\
\hline $3 R(3 r d y r)$ & 1.367 & 1.400 & 1.663 & 1.469 & 1.520 & 1.499 & 1.372 \\
\hline $3 R$ (6th $y r)$ & 1.363 & 1.397 & 1.659 & 1.465 & 1.515 & 1.495 & 1.369 \\
\hline
\end{tabular}

The breeding ratio is given for the third year, the time period in which the minimum reactivity is attained, and for the sixth year, the equilibrium situation case. The values for the sixth year are slightly lower than the values for the third year because of plutonium buildup in the radial blanket. Compared to the small pin design, the breeding ratios are a little lower because of the longer residence time.

The annual feed and discharge masses by isotope are given for the various types of plutonium in Tables A.8 to A.14 for the advanced large pin design.

CORRELATION OF ENRICHMENT WITH PLUTONIUM ISOTOPICS

The calculated feed requirements were least-squares fitted to the plutonium isotopic compositions with the following equation:

$$
\text { Atom Fraction } P_{u}=\sum_{i} A_{j} \text { (Pu Isotopic Fraction) }
$$

where

$A_{i}$ are the correlation coefficients.

The smaller the value of the coefficient, the more valuable the isotope. One should consider the value of the coefficients to be valid only within the range of isotopics used in this study. 
The coefficients are listed in Table 11 for both designs. The coefficients are nearly the same for both designs except for ${ }^{241} \mathrm{Pu}$. The coefficient for ${ }^{241} \mathrm{Pu}$ is higher for the advanced large pin design because the longer core residence time results in more ${ }^{241}$ Am buildup. The effect of increased ${ }^{241} \mathrm{Pu}$ decays is a decrease in the fraction of plutonium atoms available for fissioning, and an increase in fissile content necessary to overcome the lesser reactivity of ${ }^{241} \mathrm{Am}$. These results have also been reported in Reference 8.

TABLE 11. Correlation Coefficients for Plutonium Requirements

\begin{tabular}{|c|c|c|}
\hline Isotope & Small Pin & Advanced Large Pin \\
\hline Pu-238 & $0.186 \pm 0.005$ & $0.182 \pm 0.005$ \\
\hline Pu-239 & $0.121 \pm 0.004$ & $0.121 \pm 0.004$ \\
\hline Pu-240 & $0.254 \pm 0.014$ & $0.247 \pm 0.016$ \\
\hline$P u-241$ & $0.061 \pm 0.013$ & $0.070 \pm 0.015$ \\
\hline$P u-242$ & $0.342 \pm 0.017$ & $0.344 \pm 0.020$ \\
\hline
\end{tabular}

ENRICHED U0 2 CORES

Burnup calculations were also performed for both designs when a uranium core is enriched with ${ }^{235} \mathrm{~J}$. The results are summarized in Table 12. Both reactor designs require almost $17 \%{ }^{235} U$. The breeding ratio is slightly less than unity for each reactor. The reactivity swing during a cycle is over $2 \% \Delta \mathrm{k} / \mathrm{k}$, which is much larger than the reactivity swing for the plutonium enriched systems.

The annual feed and discharge masses by isotope are given in Table A.15 for the small pin design and Table A.16 for the advanced large pin design. The plutonium bred in the core consists of mostly ${ }^{239} \mathrm{Pu}$. The longer the core residence time, the more ${ }^{240} \mathrm{Pu}$ builds into the plutonium. 
TABLE 12. Uranium Enrichment for LMFBRs

\begin{tabular}{lccc} 
& $\begin{array}{c}\text { Small Pin } \\
\text { Design }\end{array}$ & & $\begin{array}{c}\text { Advanced } \\
\text { Large Pin Design }\end{array}$ \\
${$\cline { 2 - 2 }$} }$ & 0.156 & & 0.157 \\
$\%$ U-235 & 16.78 & 16.92 \\
$\%$ U-238 & 83.06 & 82.92 \\
Reactivity Swing, mk & -23.6 & & -22.5 \\
BR & 0.955 & & 0.957
\end{tabular}




\section{$\underline{\text { REFERENCES }}$}

1. Cantley, D. A., et a1. 1976. Core Design Parameters for the HEDL 2500 MWt Small Pin, Large Pin and Advanced Large Pin Oxide LMFBR Designs. Hanford Engineering Development Laboratory, Richland, Washington.

2. Newman, D. F. and R. M. Fleischman. 1977. "Economic Studies-Plutonium Strategy Analysis." Quarterly Progress Report LWR Fuel Recycle Program October-December 1976. BNWL-2080-3, Pac if ic Northwest Laboratory, Richland, Washington.

3. Hardie, R. W., and W. W. Little, Jr. 1969. 1DX, A One-Dimensional Diffusion Code for Generating Effective Nuclear Cross Sections. BNWL-954, Pacific Northwest Laboratory, Richland, Washington.

4. Schenter, R. E., R. B. Kidman, and J. V. Nelson. 1971. FTR Set 300, Multigroup Cross Sections for FTR Design. HEDL-TME-71-153, Hanford Engineering Development Laboratory, Richland, Washington.

5. Mann, F. M., and R. E. Schenter. 1976. "Actinide Cross-Section Calculations and Evaluations." Trans. Am. Nucl. Soc., 23:546.

6. Mann, F. M., R. E. Schenter, and D. E. Lessor. 1977. Preliminary Acti-

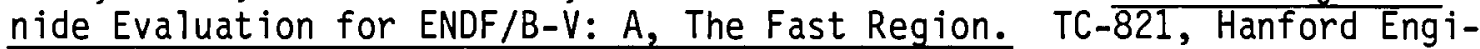
neering Development Laboratory, Richland, Washington.

7. Little, W. W. Jr., and R. W. Hardie. 1969. 2DB User's Manual -- Revision 1. BNWL-831 REV1, Pacific Northwest Laboratory, Richland, Washington.

8. Jenquin, U. P., and D. F. Newman. 1977. "Effect of Plutonium Isotopic Composition on LMFBR Fueling Requirements." Trans. Am. Nucl. Soc., 27: 902 . 
APPENDIX A

MASS-FLOW DATA 
APPENDIX A

MASS-FLOW DATA

This appendix contains the tables of mass-flow data. 
TABLE A.1. Annual Mass Flow of Isotopes for First $\mathrm{UO}_{2}$ With the Small Pin Design

\begin{tabular}{|c|c|c|c|c|c|}
\hline Isotope & \multicolumn{5}{|c|}{ Kilograms/Year } \\
\hline$\frac{\text { Feed }}{\mathrm{U}-235}$ & $\begin{array}{l}\text { Inner } \\
\text { Core } \\
10.28\end{array}$ & $\begin{array}{l}\text { Outer } \\
\text { Core } \\
9.84\end{array}$ & $\begin{array}{c}\text { Axial } \\
\text { Blanket } \\
23.58\end{array}$ & $\begin{array}{l}\text { Radial } \\
\text { Blanket } \\
19.32\end{array}$ & $\frac{\text { Total }}{63.02}$ \\
\hline U-238 & 5188 & 4976 & 11,942 & 9748 & 31,890 \\
\hline Pu-238 & 3.04 & 3.88 & & & 6.92 \\
\hline Pu-239 & 527.8 & 668.0 & & & 1195.8 \\
\hline Pu-240 & 172.4 & 218.2 & & & 390.6 \\
\hline Pu-241 & 74.42 & 94.16 & & & 168.6 \\
\hline Pu-242 & 13.82 & 17.50 & & & \\
\hline $\begin{array}{l}\text { Total } \\
\text { Fissile }\end{array}$ & \multicolumn{2}{|c|}{$1384.6^{(a)}$} & \multicolumn{2}{|c|}{$42.90^{(b)}$} & 1427.4 \\
\hline $\begin{array}{l}\text { Total } \\
\text { Heavy Metal }\end{array}$ & \multicolumn{2}{|c|}{$11,978^{(a)}$} & \multicolumn{2}{|c|}{$21.768^{(b)}$} & 33,746 \\
\hline \multicolumn{6}{|l|}{ Discharge } \\
\hline$U-235$ & 5.48 & 6.58 & 20.28 & 17.24 & 49.58 \\
\hline$U-238$ & 4778 & 4720 & 11748 & 9664 & 30,910 \\
\hline$P u-238$ & 2.10 & 3.04 & 0 & 0 & 5.14 \\
\hline Pu-239 & 572.0 & 647.8 & 174.6 & 110.58 & 1505.0 \\
\hline$P u-240$ & 204.8 & 242.8 & 3.70 & 1.78 & 456.6 \\
\hline Pu-241 & 46.44 & 65.46 & 0.08 & 0.02 & 112.0 \\
\hline$P u-242$ & 17.74 & 20.94 & - & - & 38.68 \\
\hline Am-241 & 4.32 & 6.38 & - & - & 10.70 \\
\hline $\begin{array}{l}\text { Total } \\
\text { Fissile }\end{array}$ & \multicolumn{2}{|c|}{1343.8} & \multicolumn{2}{|c|}{322.82} & 1666.6 \\
\hline $\begin{array}{l}\text { Total } \\
\text { Heavy Meta } 1\end{array}$ & \multicolumn{2}{|c|}{11,348} & \multicolumn{2}{|c|}{21,740} & 33,088 \\
\hline
\end{tabular}

(a) These values are the sum of the inner core and the outer core.

(b) These values are the sum of the axial blanket and the radial blanket. 
TABLE A.2. Annual Mass Flow of Isotopes for Equilibrium $\mathrm{UO}_{2}$ With the Small Pin Design

\begin{tabular}{|c|c|c|c|c|c|}
\hline Isotope & \multicolumn{5}{|c|}{ Kilograms/Year } \\
\hline$\frac{\text { Feed }}{\mathrm{U}-235}$ & $\begin{array}{l}\begin{array}{l}\text { Inner } \\
\text { Core }\end{array} \\
10.16\end{array}$ & $\begin{array}{l}\text { Outer } \\
\text { Core } \\
9.78\end{array}$ & $\begin{array}{c}\text { Axial } \\
\text { Blanket } \\
23.58\end{array}$ & $\begin{array}{l}\text { Radial } \\
\text { Blanket } \\
19.32\end{array}$ & $\frac{\text { Tota } 1}{62.84}$ \\
\hline$U-238$ & 5148 & 4926 & 11,942 & 9784 & 31,800 \\
\hline$P u-238$ & 12.84 & 16.18 & & & 29.02 \\
\hline$P u-239$ & 457.2 & 578.0 & & & 1035.2 \\
\hline $\mathrm{Pu}-240$ & 198.9 & 251.6 & & & 450.5 \\
\hline Pu-241 & 118.48 & 149.84 & & & 268.3 \\
\hline $\mathrm{Pu}-242$ & 44.18 & 55.84 & & & 100.02 \\
\hline $\begin{array}{l}\text { Total } \\
\text { Fissile }\end{array}$ & \multicolumn{2}{|c|}{1323.4} & \multicolumn{2}{|c|}{42.90} & 1366.4 \\
\hline $\begin{array}{l}\text { Total } \\
\text { Heavy Metal }\end{array}$ & \multicolumn{2}{|c|}{11,978} & \multicolumn{2}{|c|}{21,768} & 33,746 \\
\hline \multicolumn{6}{|l|}{ Discharge } \\
\hline$U-235$ & 5.40 & 6.54 & 20.28 & 17.24 & 49.46 \\
\hline$U-238$ & 4742 & 4674 & 11,748 & 9664 & 30,828 \\
\hline$P u-238$ & 8.88 & 12.74 & 0 & 0 & 21.62 \\
\hline$P u-239$ & 530.6 & 584.4 & 174.5 & 110.44 & 1399.8 \\
\hline$P u-240$ & 224.2 & 266.8 & 3.70 & 1.76 & 496.5 \\
\hline$P u-241$ & 67.36 & 98.80 & 0.08 & 0.02 & 166.3 \\
\hline Pu-242 & 46.98 & 58.52 & - & - & 105.50 \\
\hline Am-241 & 6.62 & 9.92 & - & - & 16.54 \\
\hline $\begin{array}{l}\text { Total } \\
\text { Fissile }\end{array}$ & \multirow{2}{*}{\multicolumn{2}{|c|}{1293.2}} & \multicolumn{2}{|c|}{322.58} & 1615.6 \\
\hline \multicolumn{4}{|l|}{ Total } & & \\
\hline Heavy Metal & \multicolumn{2}{|c|}{11,344} & \multicolumn{2}{|c|}{21,740} & 33,084 \\
\hline
\end{tabular}


TABLE A.3. Annual Mass Flow of Isotopes for Second U Recycle With the Small Pin Design

\begin{tabular}{|c|c|c|c|c|c|}
\hline Isotope & \multicolumn{5}{|c|}{ Kilograms/Year } \\
\hline$\frac{\text { Feed }}{U-235}$ & $\begin{array}{c}\text { Inner } \\
\text { Core } \\
10.22\end{array}$ & $\begin{array}{l}\text { Outer } \\
\text { Core } \\
9.84\end{array}$ & $\begin{array}{l}\text { Axial } \\
\text { Blanket } \\
23.58\end{array}$ & $\begin{array}{l}\text { Radial } \\
\text { Blanket } \\
19.32\end{array}$ & $\frac{\text { Total }}{62.96}$ \\
\hline$U-238$ & 5178 & 4962 & 11,942 & 9784 & 31,866 \\
\hline$P u-238$ & 119.60 & 151.46 & & & 271.0 \\
\hline$P u-239$ & 455.6 & 577.0 & & & 1032.6 \\
\hline$P u-240$ & 136.5 & 172.9 & & & 309.4 \\
\hline$P u-241$ & 73.78 & 93.46 & & & 167.24 \\
\hline $\mathrm{Pu}-242$ & 15.88 & 20.14 & & & 36.02 \\
\hline $\begin{array}{l}\text { Total } \\
\text { Fissile }\end{array}$ & \multicolumn{2}{|c|}{1219.8} & \multicolumn{2}{|c|}{42.90} & 1262.8 \\
\hline $\begin{array}{l}\text { Total } \\
\text { Heavy Metal }\end{array}$ & \multicolumn{2}{|c|}{11,986} & \multicolumn{2}{|c|}{21,768} & 33,746 \\
\hline \multicolumn{6}{|l|}{ Discharge } \\
\hline$U-235$ & 5.42 & 6.58 & 20.26 & 17.24 & 49.50 \\
\hline$U-238$ & 4766 & 4706 & 11,746 & 9664 & 30,882 \\
\hline $\mathrm{Pu}-238$ & 83.18 & 119.62 & 0 & 0 & 202.8 \\
\hline$P u-239$ & 538.0 & 591.2 & 175.0 & 110.8 & 1415.0 \\
\hline$P u-240$ & 173.0 & 197.5 & 3.74 & 1.78 & 376.0 \\
\hline Pu-241 & 43.70 & 62.86 & 0.08 & 0.02 & 106.66 \\
\hline $\mathrm{Pu}-242$ & 19.34 & 23.22 & - & - & 42.56 \\
\hline$A m-241$ & 4.18 & 6.24 & - & - & 10.42 \\
\hline $\begin{array}{l}\text { Total } \\
\text { Fissile }\end{array}$ & \multicolumn{2}{|c|}{1247.8} & \multicolumn{2}{|c|}{323.32} & 1571.2 \\
\hline $\begin{array}{l}\text { Total } \\
\text { Heavy Meta } 1\end{array}$ & \multicolumn{2}{|c|}{11,346} & \multicolumn{2}{|c|}{21,738} & 33,084 \\
\hline
\end{tabular}


TABLE A.4. Annual Mass Flow of Isotopes for Third U Recycle With the Small Pin Design

\begin{tabular}{|c|c|c|c|c|c|}
\hline Isotope & \multicolumn{5}{|c|}{ Kilograms/Year } \\
\hline Feed & $\begin{array}{c}\text { Inner } \\
\text { Core } \\
10.22\end{array}$ & $\begin{array}{l}\text { Outer } \\
\text { Core } \\
9.78\end{array}$ & $\begin{array}{l}\text { Axial } \\
\text { Blanket } \\
23.58\end{array}$ & $\begin{array}{l}\text { Radial } \\
\text { B lanket } \\
19.32\end{array}$ & $\frac{\text { Tota } 1}{62.90}$ \\
\hline$U-238$ & 5168 & 4950 & 11,942 & 9784 & 31,844 \\
\hline$P u-238$ & 288.4 & 364.8 & & & 653.2 \\
\hline Pu-239 & 410.8 & 519.4 & & & 930.2 \\
\hline Pu -240 & 61.04 & 77.20 & & & 138.24 \\
\hline Pu-241 & 44.70 & 56.50 & & & 101.20 \\
\hline Pu-242 & 4.78 & 6.00 & & & 10.78 \\
\hline $\begin{array}{l}\text { Total } \\
\text { Fissile }\end{array}$ & \multicolumn{2}{|c|}{1055.4} & \multicolumn{2}{|c|}{42.90} & 1094.4 \\
\hline $\begin{array}{l}\text { Total } \\
\text { Heavy Meta }\end{array}$ & \multicolumn{2}{|c|}{11,972} & \multicolumn{2}{|c|}{21,768} & 33,740 \\
\hline \multicolumn{6}{|l|}{ Discharge } \\
\hline$U-235$ & 5.42 & 6.56 & 20.30 & 17.76 & 50.04 \\
\hline$U-238$ & 4760 & 4698 & 11,748 & 9696 & 30,902 \\
\hline $\mathrm{Pu}-238$ & 202.2 & 290.0 & 0 & 0 & 492.2 \\
\hline $\mathrm{Pu}-239$ & 521.0 & 559.2 & 173.08 & 83.12 & 1336.4 \\
\hline Pu-240 & 107.08 & 109.42 & 3.66 & 1.00 & 221.16 \\
\hline$P u-241$ & 26.00 & 37.28 & 0.08 & 0.02 & 63.38 \\
\hline Pu-242 & 7.50 & 8.40 & - & - & 15.90 \\
\hline$A m-241$ & 2.50 & 3.72 & - & - & 6.22 \\
\hline $\begin{array}{l}\text { Total } \\
\text { Fissile }\end{array}$ & \multirow{2}{*}{\multicolumn{2}{|c|}{1155.4}} & \multicolumn{2}{|c|}{294.36} & 1449.8 \\
\hline \multicolumn{4}{|l|}{ Tota 1} & & \\
\hline Heavy Meta 1 & \multicolumn{2}{|c|}{11,344} & \multicolumn{2}{|c|}{21,743} & 33,087 \\
\hline
\end{tabular}


TABLE A.5. Annual Mass Flow of Isotopes for Equilibrium LMFBR With the Small Pin Design

\begin{tabular}{|c|c|c|c|c|c|}
\hline Isotope & \multicolumn{5}{|c|}{ Kilograms/Year } \\
\hline$\frac{\text { Feed }}{\mathrm{U}-235}$ & $\begin{array}{l}\text { Inner } \\
\text { Core } \\
10.22\end{array}$ & $\begin{array}{l}\text { Outer } \\
\text { Core } \\
9.78\end{array}$ & $\begin{array}{c}\text { Axial } \\
\text { B lanket } \\
23.58\end{array}$ & $\begin{array}{l}\text { Radial } \\
\frac{\text { Blanket }}{19.32}\end{array}$ & $\frac{\text { Total }}{62.90}$ \\
\hline$U-238$ & 5156 & 4936 & 11,942 & 9784 & 31,818 \\
\hline$P u-238$ & 0 & 0 & & & 0 \\
\hline$P u-239$ & 581.6 & 735.0 & & & 1316.6 \\
\hline$P u-240$ & 204.8 & 259.0 & & & 463.8 \\
\hline$P u-241$ & 24.90 & 31.44 & & & 56.34 \\
\hline Pu-242 & 12.46 & 15.82 & & & 28.28 \\
\hline $\begin{array}{l}\text { Total } \\
\text { Fissile }\end{array}$ & \multicolumn{2}{|c|}{1393.0} & \multicolumn{2}{|c|}{42.90} & 1435.8 \\
\hline $\begin{array}{l}\text { Total } \\
\text { Heavy Metal }\end{array}$ & \multicolumn{2}{|c|}{11,978} & \multicolumn{2}{|c|}{21,768} & 33,746 \\
\hline \multicolumn{6}{|l|}{ Discharge } \\
\hline$U-235$ & 5.42 & 6.54 & 20.26 & 17.24 & 49.46 \\
\hline$U-238$ & 4746 & 4682 & 11,746 & 9664 & 30,838 \\
\hline Pu-238 & 0 & 0 & 0 & 0 & 0 \\
\hline$P u-239$ & 600.6 & 692.8 & 175.2 & 110.7 & 1579.4 \\
\hline$P u-240$ & 240.2 & 283.2 & 3.74 & 1.78 & 529.0 \\
\hline Pu-241 & 26.84 & 31.52 & 0.08 & 0.02 & 58.46 \\
\hline Pu-242 & 13.32 & 16.36 & - & - & 29.68 \\
\hline$A m-241$ & 1.94 & 2.58 & - & - & 4.52 \\
\hline $\begin{array}{l}\text { Total } \\
\text { Fissile }\end{array}$ & \multicolumn{2}{|c|}{1363.8} & \multicolumn{2}{|c|}{323.54} & 1687.2 \\
\hline \multicolumn{6}{|l|}{ Total } \\
\hline
\end{tabular}


TABLE A.6. Annual Mass Flow of Isotopes for First Pu Recycle With the Small Pin Design

\begin{tabular}{|c|c|c|c|c|c|}
\hline Isotope & \multicolumn{5}{|c|}{ Kilograms/Year } \\
\hline $\begin{array}{r}\text { Feed } \\
U-235\end{array}$ & $\begin{array}{c}\text { Inner } \\
\text { Core } \\
9.98\end{array}$ & $\begin{array}{l}\text { Outer } \\
\text { Core } \\
9.52\end{array}$ & $\begin{array}{l}\text { Axial } \\
\text { Blanket } \\
23.58\end{array}$ & $\begin{array}{l}\text { Radial } \\
\text { Blanket } \\
19.32\end{array}$ & $\frac{\text { Total }}{62.40}$ \\
\hline$U-238$ & 5050 & 4802 & 11,942 & 9784 & 31,578 \\
\hline Pu-238 & 20.46 & 25.84 & & & 46.30 \\
\hline$P u-239$ & 364.2 & 460.6 & & & 824.8 \\
\hline$P u-240$ & 284.4 & 359.8 & & & 644.2 \\
\hline$P u-241$ & 167.3 & 211.6 & & & 379.0 \\
\hline$P u-242$ & 95.72 & 121.02 & & & 216.7 \\
\hline $\begin{array}{l}\text { Total } \\
\text { Fissile }\end{array}$ & \multicolumn{2}{|c|}{1223.2} & \multicolumn{2}{|c|}{42.90} & 1266.2 \\
\hline $\begin{array}{l}\text { Total } \\
\text { Heavy Meta } 1\end{array}$ & \multicolumn{2}{|c|}{11,982} & \multicolumn{2}{|c|}{21,768} & 33,750 \\
\hline \multicolumn{6}{|l|}{ Discharge } \\
\hline$U-235$ & 5.32 & 6.38 & 20.28 & 17.24 & 49.22 \\
\hline$U-238$ & 4650 & 4554 & 11,748 & 9664 & 30,616 \\
\hline Pu-238 & 14.20 & 20.36 & 0 & 0 & 34.56 \\
\hline Pu-239 & 474.0 & 499.4 & 174.42 & 110.58 & 1258.4 \\
\hline$P u-240$ & 287.2 & 355.4 & 3.70 & 1.78 & 648.0 \\
\hline Pu-241 & 93.94 & 138.88 & 0.08 & 0.02 & 233.0 \\
\hline $\mathrm{Pu}-242$ & 95.34 & 121.12 & - & - & 216.5 \\
\hline$A m-241$ & 9.30 & 13.98 & - & - & 23.28 \\
\hline $\begin{array}{l}\text { Total } \\
\text { Fissile }\end{array}$ & \multicolumn{2}{|c|}{1217.8} & \multicolumn{2}{|c|}{322.65} & 1540.6 \\
\hline $\begin{array}{l}\text { Total } \\
\text { Heavy Metal }\end{array}$ & \multicolumn{2}{|c|}{11,338} & \multicolumn{2}{|c|}{21,740} & 33,078 \\
\hline
\end{tabular}


TABLE A.7. Annual Mass Flow of Isotopes for Third Pu Recycle With the Small Pin Design

\begin{tabular}{|c|c|c|c|c|c|}
\hline Isotope & \multicolumn{5}{|c|}{ Kilograms/Year } \\
\hline Feed & $\begin{array}{l}\text { Inner } \\
\text { Core } \\
9.84\end{array}$ & $\begin{array}{l}\text { Outer } \\
\text { Core } \\
9.28\end{array}$ & $\begin{array}{c}\text { Axial } \\
\text { Blanket } \\
23.58\end{array}$ & $\begin{array}{l}\text { Radial } \\
\text { Blanket } \\
19.28\end{array}$ & $\frac{\text { Total }}{61.98}$ \\
\hline$U-238$ & 4966 & 4694 & 11,942 & 9760 & 31,366 \\
\hline$P u-238$ & 37.72 & 47.68 & & & 85.40 \\
\hline$P u-239$ & 275.2 & 347.6 & & & 622.8 \\
\hline$P u-240$ & 288.4 & 364.0 & & & 652.4 \\
\hline$P u-241$ & 219.4 & 277.0 & & & 496.4 \\
\hline Pu-242 & 197.8 & 249.8 & & & 447.6 \\
\hline $\begin{array}{l}\text { Total } \\
\text { Fissile }\end{array}$ & \multicolumn{2}{|c|}{1138.4} & \multicolumn{2}{|c|}{42.86} & 1181.2 \\
\hline $\begin{array}{l}\text { Total } \\
\text { Heavy Metal }\end{array}$ & \multicolumn{2}{|c|}{11,988} & \multicolumn{2}{|c|}{21,744} & 33,732 \\
\hline \multicolumn{6}{|l|}{ Discharge } \\
\hline$U-235$ & 5.24 & 6.20 & 20.28 & 17.66 & 49.38 \\
\hline$U-238$ & 4572 & 4456 & 11,748 & 9668 & 30,444 \\
\hline Pu-238 & 26.16 & 37.56 & 0 & 0 & 63.72 \\
\hline Pu-239 & 420.8 & 418.4 & 174.38 & 86.12 & 1099.7 \\
\hline$P u-240$ & 282.4 & 352.0 & 3.70 & 1.06 & 639.2 \\
\hline $\mathrm{Pu}-241$ & 116.88 & 176.4 & 0.04 & 0.02 & 293.4 \\
\hline Pu-242 & 187.22 & 241.4 & - & - & 428.6 \\
\hline Am-241 & 11.92 & 18.04 & - & - & 29.96 \\
\hline $\begin{array}{l}\text { Total } \\
\text { Fissile }\end{array}$ & \multicolumn{2}{|c|}{1144.0} & \multicolumn{2}{|c|}{298.54} & 1442.6 \\
\hline $\begin{array}{l}\text { Total } \\
\text { Heavy Meta } 1\end{array}$ & \multicolumn{2}{|c|}{11,328} & \multicolumn{2}{|c|}{$.21,720$} & 33,048 \\
\hline
\end{tabular}


TABLE A.8. Annual Mass Flow of Isotopes for First $\mathrm{UO}_{2}$ With the Advanced Large Pin Design

Isotope

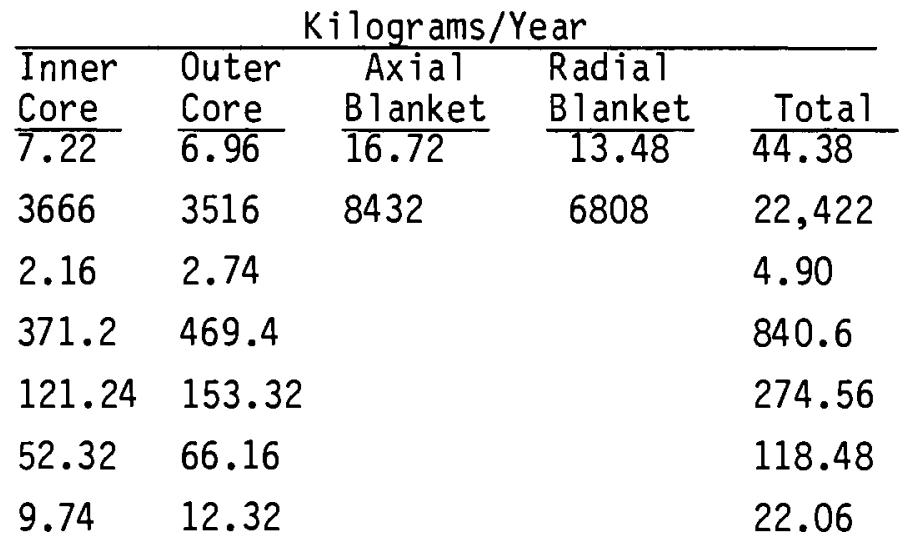

Total

Fissile

973.2

30.20

1003.4

Total

$\begin{array}{lll}\text { Heavy Metal } & 8456 & 15,270\end{array}$

Discharge

U-235

$2.94 \quad 3.96 \quad 13.52$

$11.54 \quad 31.96$

$U-238$

$3262 \quad 3264 \quad 8240$

669421,460

$\mathrm{Pu}-238$

$1.28 \quad 1.96$

0

0

3.24

Pu-239

$406.8 \quad 450.0 \quad 168.78$

$103.04 \quad 1128.6$

$\mathrm{Pu}-240$

$156.72 \quad 176.90$

5.04

2.26

341.0

$\mathrm{Pu}-241$

28.54

40.48

0.14

0.04

69.20

Pu-242

13.06

15.32

- 28.38

Am-241

3.78

5.88

$-\quad 9.66$

Total

Fissile

932.8

297.06

1229.8

Total

Heavy Meta 17834

15,238

23,072 
TABLE A.9. Annual Mass Flow of Isotopes for Equilibrium $\mathrm{UO}_{2}$ With the Advanced Large Pin Design

\begin{tabular}{|c|c|c|c|c|c|}
\hline Isotope & \multicolumn{5}{|c|}{ Kilograms/Year } \\
\hline$\frac{\text { Feed }}{U-235}$ & $\begin{array}{l}\text { Inner } \\
\text { Core } \\
7.18\end{array}$ & $\begin{array}{l}\text { Outer } \\
\text { Core } \\
\frac{6.88}{}\end{array}$ & $\begin{array}{c}\text { Axial } \\
\text { Blanket } \\
16.72\end{array}$ & $\begin{array}{l}\text { Radial } \\
\frac{\text { Blanket }}{13.48}\end{array}$ & $\frac{\text { Total }}{44.26}$ \\
\hline$U-238$ & 3636 & 3480 & 8432 & 6808 & 22,356 \\
\hline$P u-238$ & 9.04 & 11.42 & & & 20.46 \\
\hline$P u-239$ & 322.4 & 407.8 & & & 730.2 \\
\hline$P u-240$ & 140.30 & 177.42 & & & 317.7 \\
\hline$P u-241$ & 83.56 & 105.66 & & & 189.2 \\
\hline$P u-242$ & 31.14 & 39.40 & & & 70.54 \\
\hline $\begin{array}{l}\text { Total } \\
\text { Fissile }\end{array}$ & \multicolumn{2}{|c|}{933.4} & \multicolumn{2}{|c|}{30.20} & 963.6 \\
\hline $\begin{array}{l}\text { Total } \\
\text { Heavy Metal }\end{array}$ & \multicolumn{2}{|l|}{8458} & \multicolumn{2}{|c|}{15,270} & 23,728 \\
\hline \multicolumn{6}{|l|}{ Discharge } \\
\hline$U-235$ & 2.94 & 3.90 & 13.52 & 11.54 & 31.90 \\
\hline$U-238$ & 3236 & 3230 & 8240 & 6694 & 21,400 \\
\hline$P u-238$ & 5.36 & 8.16 & 0 & 0 & 13.52 \\
\hline$P u-239$ & 383.8 & 411.8 & 168.52 & 103.00 & 1067.1 \\
\hline$P u-240$ & 165.9 & 192.2 & 5.02 & 2.26 & 365.3 \\
\hline Pu-241 & 39.40 & 59.58 & 0.14 & 0.04 & 99.16 \\
\hline Pu-242 & 32.98 & 41.42 & - & - & 74.40 \\
\hline Am-241 & 5.66 & 9.06 & - & - & 14.72 \\
\hline $\begin{array}{l}\text { Total } \\
\text { Fissile }\end{array}$ & \multicolumn{2}{|l|}{901.4} & \multicolumn{2}{|c|}{296.76} & 1198.2 \\
\hline $\begin{array}{l}\text { Total } \\
\text { Heavy Metal }\end{array}$ & \multicolumn{2}{|l|}{7020} & \multicolumn{2}{|c|}{15,238} & 23,066 \\
\hline
\end{tabular}


TABLE A.10. Annual Mass Flow of Isotopes for Second U Recycle With the Advanced Large Pin Design

\begin{tabular}{|c|c|c|c|c|c|}
\hline Isotope & \multicolumn{5}{|c|}{ Kilograms/Year } \\
\hline$\frac{\text { Feed }}{\mathrm{U}-235}$ & $\begin{array}{l}\text { Inner } \\
\text { Core } \\
7.24\end{array}$ & $\begin{array}{l}\text { Outer } \\
\text { Core } \\
\frac{6.92}{6}\end{array}$ & $\begin{array}{c}\text { Axial } \\
\text { Blanket } \\
16.72\end{array}$ & $\begin{array}{l}\text { Radial } \\
\text { Blanket } \\
13.48\end{array}$ & $\frac{\text { Total }}{44.36}$ \\
\hline$U-238$ & 3660 & 3508 & 8432 & 6808 & 22,408 \\
\hline$P u-238$ & 83.88 & 106.24 & & & 190.12 \\
\hline Pu-239 & 319.6 & 404.8 & & & 724.4 \\
\hline$P u-240$ & 95.76 & 121.28 & & & 217.0 \\
\hline Pu-241 & 51.74 & 65.54 & & & 117.28 \\
\hline Pu-242 & 11.12 & 14.12 & & & 25.24 \\
\hline $\begin{array}{l}\text { Total } \\
\text { Fissile }\end{array}$ & \multicolumn{2}{|c|}{855.8} & \multicolumn{2}{|c|}{30.20} & 886.0 \\
\hline $\begin{array}{l}\text { Total } \\
\text { Heavy Metal }\end{array}$ & \multicolumn{2}{|l|}{8456} & \multicolumn{2}{|c|}{15,270} & 23,726 \\
\hline \multicolumn{6}{|l|}{ Discharge } \\
\hline$U-235$ & 2.92 & 3.92 & 13.52 & 11.54 & 31.90 \\
\hline$U-238$ & 3254 & 3256 & 8240 & 6694 & 21,444 \\
\hline Pu-238 & 50.00 & 76.34 & 0 & 0 & 126.34 \\
\hline$P u-239$ & 389.4 & 416.8 & 168.96 & 102.98 & 1078.2 \\
\hline$P u-240$ & 132.42 & 145.14 & 5.04 & 2.26 & 284.9 \\
\hline$P u-241$ & 26.24 & 38.26 & 0.14 & 0.04 & 64.68 \\
\hline Pu-242 & 13.96 & 16.76 & - & - & 30.72 \\
\hline$A m-241$ & 3.58 & 5.70 & - & - & 9.28 \\
\hline $\begin{array}{l}\text { Total } \\
\text { Fissile }\end{array}$ & \multicolumn{2}{|l|}{877.6} & \multicolumn{2}{|c|}{297.18} & 1174.8 \\
\hline $\begin{array}{l}\text { Total } \\
\text { Heavy Metal }\end{array}$ & \multicolumn{2}{|l|}{7832} & \multicolumn{2}{|c|}{15,238} & 23,070 \\
\hline
\end{tabular}


TABLE A.11. Annual Mass Flow of Isotopes for Third U Recycle With the Advanced Large Pin Design

\begin{tabular}{|c|c|c|c|c|c|}
\hline Isotope & \multicolumn{5}{|c|}{ Kiglograms/Year } \\
\hline$\frac{\text { Feed }}{U-235}$ & $\begin{array}{l}\text { Inner } \\
\text { Core } \\
7.24\end{array}$ & $\begin{array}{l}\text { Outer } \\
\text { Core } \\
6.92\end{array}$ & $\begin{array}{c}\text { Axial } \\
\text { Blanket } \\
16.72\end{array}$ & $\begin{array}{l}\text { Radial } \\
\frac{\text { Blanket }}{13.48}\end{array}$ & $\frac{\text { Tota } 1}{44.36}$ \\
\hline$U-238$ & 3656 & 3504 & 8432 & 6808 & 22,400 \\
\hline$P u-238$ & 201.2 & 254.6 & & & 455.8 \\
\hline$P u-239$ & 286.6 & 362.4 & & & 649.0 \\
\hline$P u-240$ & 42.58 & 53.84 & & & 96.42 \\
\hline$P u-241$ & 31.18 & 39.42 & & & 70.60 \\
\hline Pu-242 & 3.32 & 4.22 & & & 7.54 \\
\hline $\begin{array}{l}\text { Total } \\
\text { Fissile }\end{array}$ & \multicolumn{2}{|c|}{733.8} & \multicolumn{2}{|c|}{30.20} & 764.0 \\
\hline $\begin{array}{l}\text { Total } \\
\text { Heavy Metal }\end{array}$ & \multicolumn{2}{|l|}{8454} & \multicolumn{2}{|c|}{15,270} & 23,724 \\
\hline \multicolumn{6}{|l|}{ Discharge } \\
\hline$U-235$ & 2.94 & 3.96 & 13.54 & 11.56 & 32.00 \\
\hline$U-238$ & 3252 & 3256 & 8242 & 6696 & 21,446 \\
\hline$P u-238$ & 121.46 & 184.68 & 0 & 0 & 306.14 \\
\hline Pu-239 & 381.8 & 398.6 & 167.10 & 101.52 & 1049.0 \\
\hline$P u-240$ & 88.78 & 85.20 & 4.94 & 2.20 & 181.12 \\
\hline$P u-241$ & 15.86 & 22.58 & 0.14 & 0.04 & 38.62 \\
\hline Pu-242 & 5.64 & 6.30 & - & - & 11.94 \\
\hline Am-241 & 2.14 & 3.38 & - & - & 5.52 \\
\hline $\begin{array}{l}\text { Total } \\
\text { Fissile }\end{array}$ & \multicolumn{2}{|l|}{825.8} & \multicolumn{2}{|c|}{293.9} & 1119.6 \\
\hline $\begin{array}{l}\text { Total } \\
\text { Heavy Meta } 1\end{array}$ & \multicolumn{2}{|l|}{7832} & \multicolumn{2}{|c|}{15,240} & 23,070 \\
\hline
\end{tabular}


TABLE A.12. Annual Mass Flow of Isotopes for Equilibrium LMFBR With the Advanced Large Pin Design

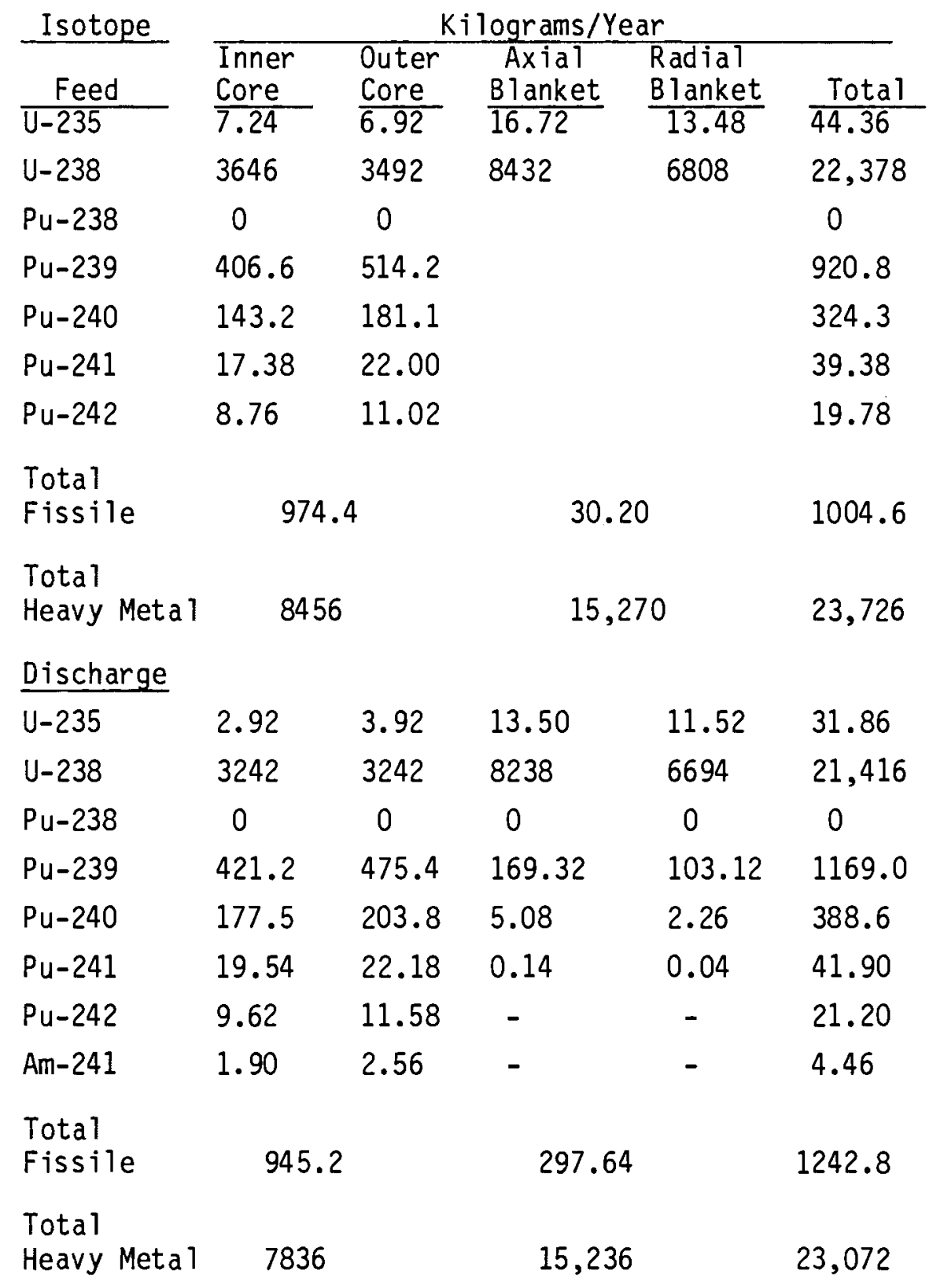


TABLE A.13. Annual Mass Flow of Isotopes for First Pu Recycle With the Advanced Large Pin Design

\begin{tabular}{|c|c|c|c|c|c|}
\hline Isotope & \multicolumn{5}{|c|}{ Kilograms/Year } \\
\hline$\frac{\text { Feed }}{U-235}$ & $\begin{array}{l}\text { Inner } \\
\text { Core } \\
7.06\end{array}$ & $\begin{array}{l}\text { Outer } \\
\text { Core } \\
6.70\end{array}$ & $\begin{array}{c}\text { Axial } \\
\text { Blanket } \\
16.72\end{array}$ & $\begin{array}{l}\text { Radial } \\
\text { Blanket } \\
13.48\end{array}$ & $\frac{\text { Total }}{43.96}$ \\
\hline$U-238$ & 3568 & 3392 & 8432 & 6808 & 22,200 \\
\hline$P u-238$ & 14.38 & 18.20 & & & 32.58 \\
\hline$P u-239$ & 256.4 & 324.4 & & & 580.8 \\
\hline$P u-240$ & 200.2 & 253.4 & & & 453.6 \\
\hline$P u-241$ & 117.8 & 149.0 & & & 266.8 \\
\hline $\mathrm{Pu}-242$ & 67.40 & 85.26 & & & 152.66 \\
\hline $\begin{array}{l}\text { Total } \\
\text { Fissile }\end{array}$ & \multicolumn{2}{|c|}{861.4} & \multicolumn{2}{|c|}{30.20} & 891.6 \\
\hline $\begin{array}{l}\text { Total } \\
\text { Heavy Meta } 1\end{array}$ & \multicolumn{2}{|c|}{8460} & \multicolumn{2}{|c|}{15,270} & 23,730 \\
\hline \multicolumn{6}{|l|}{ Discharge } \\
\hline$U-235$ & 2.88 & 3.80 & 13.52 & 11.52 & 31.72 \\
\hline$U-238$ & 3174 & 3148 & 8240 & 6694 & 21,256 \\
\hline Pu-238 & 8.54 & 13.02 & 0 & 0 & 21.56 \\
\hline Pu-239 & 351.0 & 358.8 & 168.66 & 103.20 & 981.6 \\
\hline$P u-240$ & 205.0 & 249.8 & 5.02 & 2.26 & 462.0 \\
\hline Pu-241 & 53.94 & 83.16 & 0.14 & 0.04 & 137.28 \\
\hline Pu-242 & 65.72 & 84.50 & - & - & 150.22 \\
\hline$A m-241$ & 7.90 & 12.72 & - & - & 20.62 \\
\hline $\begin{array}{l}\text { Total } \\
\text { Fissile }\end{array}$ & \multicolumn{2}{|c|}{853.6} & \multicolumn{2}{|c|}{297.08} & 1150.6 \\
\hline $\begin{array}{l}\text { Total } \\
\text { Heavy Metal }\end{array}$ & \multicolumn{2}{|c|}{7822} & \multicolumn{2}{|c|}{15,238} & 23,060 \\
\hline
\end{tabular}


TABLE A.14. Annual Mass Flow of Isotopes for Third Pu Recycle With the Advanced Large Pin Design

\begin{tabular}{|c|c|c|c|c|c|}
\hline Isotope & \multicolumn{5}{|c|}{ Kilograms/Year } \\
\hline$\frac{\text { Feed }}{U-235}$ & $\begin{array}{l}\begin{array}{l}\text { Inner } \\
\text { Core }\end{array} \\
6.92\end{array}$ & $\begin{array}{l}\begin{array}{l}\text { Outer } \\
\text { Core }\end{array} \\
6.58\end{array}$ & $\begin{array}{l}\text { Axial } \\
\text { Blanke } \\
16.72\end{array}$ & $\begin{array}{l}\text { Radial } \\
\text { Blanket } \\
13.48\end{array}$ & $\frac{\text { Total }}{43.70}$ \\
\hline$U-238$ & 3506 & 3316 & 8432 & 6808 & 22,062 \\
\hline$P u-238$ & 26.66 & 33.68 & & & 60.34 \\
\hline$P u-239$ & 194.7 & 245.6 & & & 440.2 \\
\hline$P u-240$ & 203.8 & 257.4 & & & 461.2 \\
\hline$P u-241$ & 155.1 & 195.8 & & & 350.9 \\
\hline Pu-242 & 139.9 & 176.5 & & & 316.4 \\
\hline $\begin{array}{l}\text { Total } \\
\text { Fissile }\end{array}$ & \multicolumn{2}{|c|}{804.6} & \multicolumn{2}{|c|}{30.20} & 835.0 \\
\hline $\begin{array}{l}\text { Total } \\
\text { Heavy Metal }\end{array}$ & \multicolumn{2}{|c|}{8464} & \multicolumn{2}{|c|}{15,270} & 23,734 \\
\hline \multicolumn{6}{|l|}{ Discharge } \\
\hline$U-235$ & 2.84 & 3.72 & 13.52 & 11.54 & 31.62 \\
\hline$U-238$ & 3118 & 3078 & 8240 & 6694 & 21,130 \\
\hline$P u-238$ & 15.86 & 24.08 & 0 & 0 & 39.94 \\
\hline Pu-239 & 320.4 & 309.2 & 168.34 & 103.06 & 901.0 \\
\hline Pu-240 & 200.8 & 246.6 & 5.00 & 2.26 & 454.6 \\
\hline$P u-241$ & 65.58 & 104.3 & 0.14 & 0.04 & 169.9 \\
\hline Pu-242 & 127.7 & 167.1 & - & - & 294.8 \\
\hline Am-241 & 10.06 & 24.08 & - & - & 34.14 \\
\hline $\begin{array}{l}\text { Total } \\
\text { Fissile }\end{array}$ & \multicolumn{2}{|c|}{806.0} & \multicolumn{2}{|c|}{296.64} & 1102.6 \\
\hline $\begin{array}{l}\text { Total } \\
\text { Heavy Meta }\end{array}$ & \multicolumn{2}{|c|}{7818} & \multicolumn{2}{|c|}{15,238} & 23,056 \\
\hline
\end{tabular}


TABLE A.15. Annual Mass Flow of Isotopes for Enriched $\mathrm{UO}_{2}$ With the Small Pin Design

\begin{tabular}{|c|c|c|c|c|c|}
\hline Isotope & \multicolumn{5}{|c|}{ Kilograms/Year } \\
\hline$\frac{\text { Feed }}{U-234}$ & $\begin{array}{l}\text { Inner } \\
\text { Core } \\
7.92\end{array}$ & $\begin{array}{l}\text { Outer } \\
\text { Core } \\
\frac{10.42}{10.42}\end{array}$ & $\begin{array}{c}\text { Axial } \\
\text { Blanket } \\
0\end{array}$ & $\begin{array}{l}\text { Radial } \\
\text { Blanket } \\
0\end{array}$ & $\frac{\text { Total }}{18.34}$ \\
\hline$U-235$ & 860.4 & 1122.0 & 23.58 & 19.32 & 2025.3 \\
\hline $\mathrm{U}-238$ & 5106 & 4834 & 11,942 & 9784 & 31,666 \\
\hline $\begin{array}{l}\text { Total } \\
\text { Fissile }\end{array}$ & \multicolumn{2}{|c|}{1982.4} & \multicolumn{2}{|l|}{42.90} & $2,025.3$ \\
\hline $\begin{array}{l}\text { Total } \\
\text { Heavy Metal }\end{array}$ & \multicolumn{2}{|c|}{11,941} & \multicolumn{2}{|l|}{21,769} & 33,710 \\
\hline \multicolumn{6}{|l|}{ Discharge } \\
\hline$U-234$ & 6.76 & 9.36 & 0 & 0 & 16.12 \\
\hline$U-235$ & 536.0 & 827.0 & 20.84 & 17.58 & 1401.4 \\
\hline$U-238$ & 4796 & 4642 & 11,780 & 9684 & 30,902 \\
\hline$P u-238$ & 0.18 & 0.04 & 0 & 0 & 0.22 \\
\hline Pu-239 & 216.6 & 141.5 & 146.10 & 93.56 & 597.7 \\
\hline Pu-240 & 10.10 & 4.04 & 2.48 & 1.22 & 17.84 \\
\hline Pu-241 & 0.24 & 0.06 & 0.04 & 0.02 & 0.36 \\
\hline Pu-242 & - & - & - & - & - \\
\hline $\begin{array}{l}\text { Total } \\
\text { Fissile }\end{array}$ & \multicolumn{2}{|c|}{1721.4} & \multicolumn{2}{|c|}{278.14} & 1999.5 \\
\hline $\begin{array}{l}\text { Total } \\
\text { Heavy Metal }\end{array}$ & \multicolumn{2}{|c|}{11,190} & \multicolumn{2}{|l|}{21,746} & 32,936 \\
\hline
\end{tabular}


TABLE A.16. Annual Mass Flow of Isotopes for Enriched $\mathrm{UO}_{2}$ With the Advanced Large Pin Design

\begin{tabular}{|c|c|c|c|c|c|}
\hline Isotope & \multicolumn{5}{|c|}{ Kilograms/Year } \\
\hline$\frac{\text { Feed }}{U-234}$ & $\begin{array}{l}\begin{array}{l}\text { Inner } \\
\text { Core }\end{array} \\
5.64\end{array}$ & $\begin{array}{l}\text { Outer } \\
\text { Core } \\
7.42\end{array}$ & $\begin{array}{c}\text { Axial } \\
\text { Blanket } \\
0\end{array}$ & $\begin{array}{l}\text { Radial } \\
\text { Blanket } \\
0\end{array}$ & $\frac{\text { Total }}{13.06}$ \\
\hline$U-235$ & 610.6 & 796.0 & 16.72 & 13.48 & 1436.8 \\
\hline$U-238$ & 3602 & 3410 & 8432 & 6808 & 22,252 \\
\hline $\begin{array}{l}\text { Total } \\
\text { Fissile }\end{array}$ & \multicolumn{2}{|c|}{1406.6} & \multicolumn{2}{|l|}{30.20} & 1436.8 \\
\hline $\begin{array}{l}\text { Total } \\
\text { Heavy Metal } 1\end{array}$ & \multicolumn{2}{|c|}{8432} & \multicolumn{2}{|l|}{15,270} & 23,702 \\
\hline \multicolumn{6}{|l|}{ Discharge } \\
\hline$U-234$ & 4.48 & 6.34 & 0 & 0 & 10.82 \\
\hline$U-235$ & 309.6 & 510.8 & 14.04 & 11.80 & 846.2 \\
\hline$U-238$ & 3294 & 3214 & 8270 & 6710 & 21,488 \\
\hline$P u-238$ & 0.34 & 0.10 & 0 & 0 & 0.44 \\
\hline$P u-239$ & 198.2 & 135.2 & 143.28 & 89.42 & 566.1 \\
\hline$P u-240$ & 13.50 & 5.68 & 3.44 & 1.62 & 24.24 \\
\hline$P u-241$ & 0.42 & 0.12 & 0.08 & 0.02 & 0.64 \\
\hline$P u-242$ & .02 & - & - & - & 0.02 \\
\hline $\begin{array}{l}\text { Total } \\
\text { Fissile }\end{array}$ & \multicolumn{2}{|c|}{1154.3} & \multicolumn{2}{|l|}{258.64} & 1412.9 \\
\hline $\begin{array}{l}\text { Total } \\
\text { Heavy Metal }\end{array}$ & \multicolumn{2}{|c|}{7693} & \multicolumn{2}{|l|}{15,244} & 22,937 \\
\hline
\end{tabular}




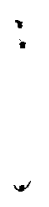




\section{DISTRIBUTION}

No. of

Copies

\section{OFFSITE}

2 W. W. Ballard

U.S. Department of Energy-HQ/FCD Washington, DC 20545

S. McDowe 11

U.S. Department of Energy-HQ/OSS

Washington, DC 20545

P. R. Clark

U.S. Department of Energy-HQ/DNR Washington, DC 20545

D. E. Bailey

U.S. Department of Energy-HQ/RRT Washington, DC 20545

R. H. Steele

U.S. Department of Energy-HQ/DNR

Washington, DC 20545

W. M. Shaffer III

U.S. Department of Energy

Savannah River Operations Office P.0. Box "A"

Aiken, SC 29801

S. W. Ahrends

U.S. Department of Energy

Oak Ridge Operations Office

P.0. Box "E"

Oak Ridge, TN 37830

A. Mravca

U.S.Department of Energy

Chicago Operations Office

9800 South Cass Avenue

Argonne, IL 60439

J. J. Keating

U.S. Department of Energy

FFTFPO

P.O. Box 550

Richland, WA 99352
No. of

Copies

M. J. Ste indler

Argonne National Laboratory

9700 South Cass Avenue

Argonne, IL 60439

C. Youe 11

Babcock \& Wilcox

P.0. Box 1260

Lynchburg, VA 24505

W. A. Weinreich

Bettis Atomic Power Laboratory

Westinghouse Electric Corp.

P.0. Box 79

West Mifflin, PA 15122

E. Zebroski

Electric Power Research Institute 3412 Hillview Avenue

Palo Alto, CA 94304

P. Miller

General Electric Company

175 Curtner Avenue

San Jose, CA 95125

G. R. Keep in

Los Alamos Scientific Laboratory

P.0. Box 1663

Los Alamos, NM 37545

A. L. Lotts

Oak Ridge National Laboratory

P.0. Box " $X$ "

Oak Ridge, TN 37830

A. Camp

Sandia Laboratory

Albuquerque, NM 87185

J. D. Spencer

Savannah River Laboratory

E.I. duPont deNemours \& Co.

Aiken, SC 29801 
No. of

Copies

C. Palmer

Westinghouse Nuclear Fuels

Division

Westinghouse Electric Company

P.0. Box 355

Pittsburgh, PA 15230

E. W. Neben

Fluor Engineers and

Constructors, Inc.

3333 Michelson Drive

Irvine, CA 92730

K. L. Highfil1

Gas Cooled Reactor Aassociates

Suite 3003344 N. Torrey Pines Ct.

LaJolla, CA 92037

W. V. Goedde 1

General Atomic Company

P.0. Box 81608

San Diego, CA 92138

D. J. Groetch

Knolls Atomic Power Laboratory

P.0. Box 1072

Schenectady, NY 12301

Department of Nuclear Engineering

Kansas State University

Manhattan, KS 66502

Department of Nuclear Engineering University of Washington

Seattle, WA. 98195

A. A. Churm

DOE Patent Division

9800 South Cass Avenue

Argonne, IL 60439

6 U.S. Department of Energy

Technical Information Center

Washington, DC 20545

27 DOE Technical Information Center
No. of

Copies

ONSITE

2 DOE Richland Operations Office

P. A. Craig

H. E. Ransom

2 Hanford Engineering Deve lopment

Laboratory

E. A. Evans

W. E. Roake

Exxon Nuclear Company

0. Kruger

65 Pacific Northwest Laboratory

W. J. Bailey

A. J. Boege 1

D. W. Brite

C. L. Brown

J. R. Carrel1

T. D. Chikalla

E. D. Clayton

D. A. Dingee

E. A. Eschbach

W. D. Felix

R. M. Fleischman

S. Goldsmith

P. E. Hart

U. P. Jenquin (20)

R. S. Kemper

L. R. Lambert

R. C. Liikala

J. F. Nesbitt

D. F. Newman

A. M. Nolan

A. M. Platt

D. L. Prezbindowsk $i$

R. E. Schrieber

R. E. Sharp

M. K. White

Publishing Coordination (2)

Technical Information (5)

FRAD Program Office Files (14) 